\title{
The Mismatch of Students Anthropometric Data with Ergonomic Designs of Learning Workstation is a Risk Factor for Musculoskeletal Disorders
}

\author{
Abanum Iruoghene Isapka ${ }^{1}$, Oriri Asemota Omorodion ${ }^{1}$
}

${ }^{1}$ Department of Industrial Safety \& Environmental Technology, Petroleum Training Institute, Delta State, Nigeria

\begin{abstract}
This study examined the relationship between anthropometric data of Nigerian Students in Higher Academic Institutions, the ergonomic design of classroom furniture and the risk of Musculoskeletal Disorders (MSDs). A total of one hundred and seventy five (175) students, aged between 17-34 years, in thirty one (31) randomly selected classrooms participated in the research. Students' anthropometric data were collated by measuring various body dimensions such as sitting elbow height, shoulder height, knee height, popliteal height, buttockpopliteal length, and stature, using anthropometer, and measuring tape. Also, classroom furniture dimensions were measured with metal measuring tape, vernier caliper and goniometer. A survey was conducted using questionnaire to identify the body areas of discomfort (MSDs) experienced by students. It was established that, there are three different types of furniture (A, B and C). This study revealed that there is a mismatch between available classroom furniture and students' anthropometric data, which is responsible for the musculoskeletal disorders complaints by the students. It is expected that the study will help decision makers and analysts in designing appropriate learning workstations using various students' anthropometric data in order to avoid the risk of musculoskeletal disorders.
\end{abstract}

Keywords: Classroom, Anthropometric Data, Ergonomic Design, Musculoskeleta Disorders

\section{Introduction}

Classrooms are integral parts of academic institution that facilitates learning, study and research. It's an academic environment for students, lecturers, etc; therefore the comfort of users of the Classroom is paramount for their better performance, because effective study and research are encouraged. The knowledge and application of ergonomics and anthropometry is imperative to ensure a healthy and productive individual. This knowledge appears lacking in many schools, and accounts for the discomfort and health hazards plaguing many Students. It is therefore necessary for every institution to consider ergonomics while designing its classroom furniture, as this would affect its overall productivity.

Anthropometric measurements whenever considered for designing classroom furniture helps students in achieving comfort ability, reducing Musculoskeletal disorders (MSDs), and improve performance of students in terms of attentiveness in class (Mokdad and Al-Ansari, 2009). Specific measurements, such as popliteal height, knee height, buttock-popliteal length and elbow height are essential in order to determine school furniture dimensions that enable the proper sitting posture.
The importance of well-designed furniture for schools cannot be over emphasized in ensuring student don't adopt awkward posture while performing a certain task i.e. writing, lectures, drawing, reading on desk tops, etc. thus preventing psychological stress that can impose ill effects on students' performance. Ergonomically designed learning environment allows for maximum adjustability of the tools and equipment which is a key factor in creating a safe environment for learning (Dawal et al., 2015).

Several reports have linked musculoskeletal disorders (MSDs) to classroom learning workstation designs, which might make students adopt awkward body posture. MSDs are said to be injuries or pain experienced in the joints of the body, muscles, ligaments, tendons, nerves, and structures that support limbs, back and neck (Baharampour et al., 2013), which impairs normal activities of the students. Most learning environment nowadays especially classroom related environment often require students to sit on the benches for prolong hours. Sitting with wrong posture for a long time can be irritating. Appropriate sitting posture is an important element in the prevention of musculoskeletal symptoms (Aleksandar et al., 2013). A data base for Nigerian students anthropometric measurements should be developed now, to enable intending designers make

This article is published under the terms of the Creative Commons Attribution License 4.0 Author(s) retain the copyright of this article. Publication rights with Alkhaer Publications.

Published at: http://www.ijsciences.com/pub/issue/2019-02/

DOI: 10.18483/ijSci.1913; Online ISSN: 2305-3925; Print ISSN: 2410-4477 
ergonomic furniture, which can provide comfortability, safety, increase productivity level and ultimately reduce Musculoskeletal disorders (MSDs).

\section{LITERATURE REVIEW}

Students are at special risk for suffering negative effects from badly designed and ill-fitting furniture owing to the prolonged periods spent seated during school. It is for these reasons that public health concerns over the effects of bad posture with focus on the design of classroom furniture. Recent researches have documented an increase in health problems related to poor sitting (Chung and Wong, 2007; Saarni et al., 2009; Corlett, 2009). Neck, shoulder and back pain problems are common among school children (Taimela et al., 1997; Alnaser and Wughalter, 2009,). Students experience such problems due to low-quality design school tables and chairs (Troussier et al., 1999). Nonadjustable school furniture forces the students to adapted poor sitting postures (Vikat et al., 2000; Koskelo, 2007; Mokdad and Al-Ansari, 2009). Neck, upper back, and lower back pain were significantly associated with school furniture features (Wingrat and Exner, 2005, Momodu et al. 2014). Researchers have conducted various studies on the evaluation of classroom ergonomic factors in relation to productivity, efficiency and comfort with regards to the design of classroom furniture based on the anthropometry data of the students. Khalid et al., (2013), reported a significantly low discomfort rate for sitting on ergonomically adjustable school furniture compared to nonadjustable school furniture. Parcells et al., (1999) and Samira, (2013) reported a substantial degree of mismatch between the bodily dimensions of the students and the classroom furniture available to them. Also, Qutubuddin et al., (2013) study showed that the existing classrooms furniture were far from compatible with the anthropometric measurements of the students which forced them to adopt unnatural postures.

Several factors, such as inappropriate desk height, lack of adequate space for the legs under the desks, lack of adjustability of the slope of the seat and seatback, high depth of chairs and their inappropriateness are among the factors responsible for a high percentage of musculoskeletal injuries facing Iran University Students, (Chubineh et al., (2012); Dianat et al., (2013) and Yadollah et al., (2015)

Although there are limited studies regarding furniture design for students in Nigeria schools, some research have reported a strong relationship between the workstation set up and development of musculoskeletal discomfort in classrooms and offices ( Nwaogazie, 2016, Momodu et al., 2014). Also, Johnson et al., (2008) reported that the poorly ergonomically designed furniture made Nigeria Universities computer users to assume bad postures while working on the computer; which they claimed make them experience eye strain, neck, back and finger pains. Musa et al., (2013) found out that the seats and tables in the tertiary institutions did not meet the ergonomic standard in relation to the anthropometry data obtained from Nigerian students and proposed new classroom furniture design. However, Ogedengbe, (2015) reported that the dimensions of the existing furniture were compatible with the values estimated from the anthropometric data of the library users.

Majority of colleges or universities administration's procure ready-made furniture which mostly fit few users (Biswas et al., 2014). Continuation of such habit of procuring ready manufactured furniture without giving attention to anthropometric measurements of students can results to uncomfortability, musculoskeletal disorders (MSDs) and can also reduce the performance of students (Hafezi et al., 2010; Dianat, et al., 2013; John and Adeyemi 2015; Close. et al., 2013; Musa, 2011).

Studies that provide empirical evidence on the extent and the nature of a possible mismatch between school furniture and student body dimensions are rare. This study therefore, assess the suitability of classroom designs of learning workstation with student anthropometric data, as possible risk factors for Musculoskeletal disorders (MSDs) amongst tertiary Institution students in the South-South region of Nigeria.

\section{METHODOLOGY}

Present study was focused on a Training Institute in the South-South region of Nigeria, to explore the types of furniture used in the different classrooms and their suitability with the user populations. One hundred and seventy five (175) students aged between 17-34 years, from thirty one (31) randomly selected classrooms participated in this study. The collection of all required anthropometric dimensions from Nigerian students adapted ISO 7250 as the standard for all selected student's body dimensions. Fig. 1 and 2 shows all body dimensions which were selected for this study with body weight as the additional body measurement. All students' anthropometric characteristics were directly measured using measuring tape, anthropometer, and weighing scale was used to measure body weight. Relevant dimensions of classroom furniture were measured, they included; Seat Height, Seat Depth, Seat Width, Seat Backrest Height (Upper and Lower), using measuring tapes, vernier caliper and goniometer. Furniture dimensions were compared with anthropometric dimensions of the students to check the suitability of design. 


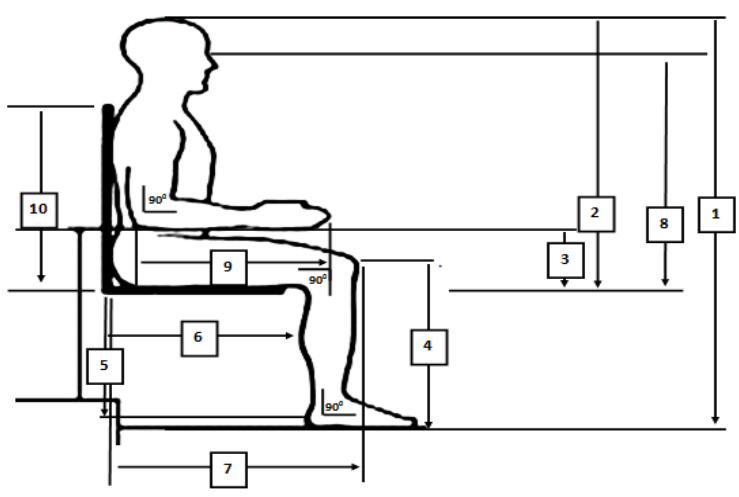

Fig 1: Some of the Measured Anthropometry Data in the Frankfurt Plane

Legend

$\mathbf{1}$ - Sitting Stature

5 - Popliteal Height

8 - Sitting Eye Height

2-Sitting Height $\quad 6$ - Buttock Popliteal Height

9 - Forearm Hand Length

3 -Sitting Elbow Height 7 -Buttock Knee Length 10 - Sitting Shoulder Height

4 - Sitting Knee Height

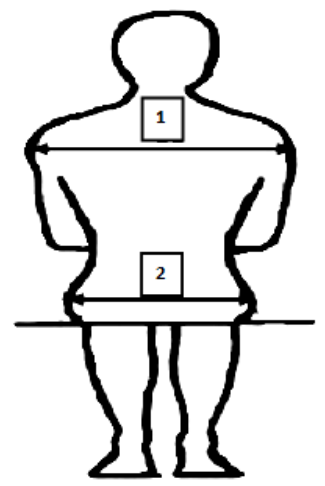

Fig 2: Some of the Measured Anthropometry Data in the Frontal Plane

Legend:

1 - Shoulder Breadth

Breadth
Description of the Body Dimensions according to ISO 7250

(i) Sitting Stature (Body Height) - Vertical distance from the floor to the highest point of the head (vertex).

(ii) Sitting Height (Erect) - Vertical distance from a horizontal sitting surface to the highest point of the head (vertex).

(iii) Shoulder Height (Sitting) - Vertical distance from a horizontal sitting surface to the acromion.

(iv) Popliteal Height (Lower Leg Length) Vertical distance from the foot-rest surface to the lower surface of the thigh immediately behind the knee, bent at right angle.

(v) Hip Breadth - Sitting Breadth of the body measured across the widest portion of the hips. Elbow Height (Sitting) - Vertical distance from a horizontal sitting surface to the lowest bony point of the elbow bent at a right angle with the forearm horizontal.

(vii) Buttock-popliteal length (Seat Depth) Horizontal distance from the hollow of the knee to the rearmost point of the buttock.

(viii) Buttock-Knee Length - Horizontal distance from the foremost point of the knee-cap to the rearmost point of the buttock.

(ix) Thigh Clearance - Vertical distance from the sitting surface to the highest point on the thigh.

(x) Eye Height (Sitting) - Vertical distance from a horizontal sitting surface to the outer corner of the eye.

(xi) Shoulder Breadth (Sitting) - Distance across the maximum lateral protrusions of the right and left deltoid muscles.

(xii) Knee Height - Vertical distance from the floor to the highest point of the superior body of the patella.

Results

Table 1: The relevant student body dimensions and the determinant anthropometry measures for school furniture
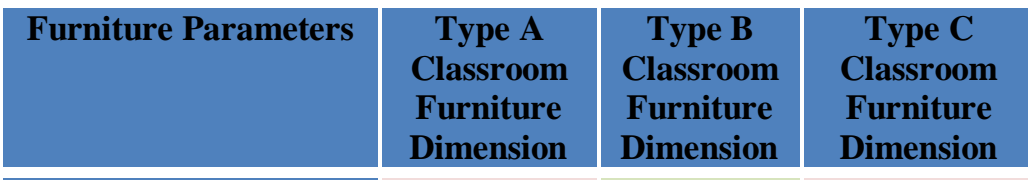

$45 \mathrm{~cm}$

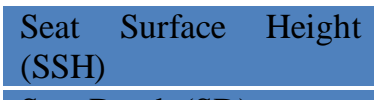

\begin{tabular}{|l|}
\hline Seat Depth (SD) \\
\hline Seat Width (SW) \\
\hline Backrest Height (BH) \\
\hline Armrest Height (AH) \\
\hline
\end{tabular}

$45 \mathrm{~cm}$
$37 \mathrm{~cm}$
$41 \mathrm{~cm}$
$47 \mathrm{~cm}$
No Armrest

$53 \mathrm{~cm}$

$37 \mathrm{~cm}$

$41 \mathrm{~cm}$

$40 \mathrm{~cm}$

No Armrest

\section{$43 \mathrm{~cm}$}

$48 \mathrm{~cm}$

$63 \mathrm{~cm}$

$7 \mathrm{~cm}$

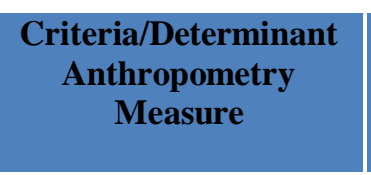

Popliteal Height (PH)

Mean Student
Anthropometry
Data

Buttock Popliteal Length (BPL)

Hip Breadth (HB)

Shoulder Height (SH)

Sitting Elbow Height
$53 \mathrm{~cm}$

$44 \mathrm{~cm}$

$39 \mathrm{~cm}$

$53 \mathrm{~cm}$ 
The Mismatch of Students Anthropometric Data with Ergonomic Designs of Learning Workstation is a Risk Factor for Musculoskeletal Disorders

\begin{tabular}{|l|l|l|l|l|l|}
\hline & & & & \multicolumn{3}{l}{$\begin{array}{l}\text { SEH) } \\
\text { Table Height (TH) }\end{array}$} & $88 \mathrm{~cm}$ & $88 \mathrm{~cm}$ & $77 \mathrm{~cm}$ & $\begin{array}{l}\text { Sitting Elbow Height }+ \\
\text { Popliteal Height + Shoe } \\
\text { Heel Allowance (SHA) }\end{array}$ & $70 \mathrm{~cm}$ \\
\hline Table Depth (TD) & $29 \mathrm{~cm}$ & $29 \mathrm{~cm}$ & $43 \mathrm{~cm}$ & $\begin{array}{l}\text { Forearm Hand Length } \\
\text { (FHL) }\end{array}$ & $42 \mathrm{~cm}$ \\
\hline Table Width (TW) & $45 \mathrm{~cm}$ & $45 \mathrm{~cm}$ & $51 \mathrm{~cm}$ & Shoulder Breadth (SB) & $44 \mathrm{~cm}$ \\
\hline $\begin{array}{l}\text { Seat Backrest Width } \\
\text { (SBW) }\end{array}$ & $40 \mathrm{~cm}$ & $42 \mathrm{~cm}$ & $48 \mathrm{~cm}$ & Shoulder Breadth (SB) & $44 \mathrm{~cm}$ \\
\hline
\end{tabular}

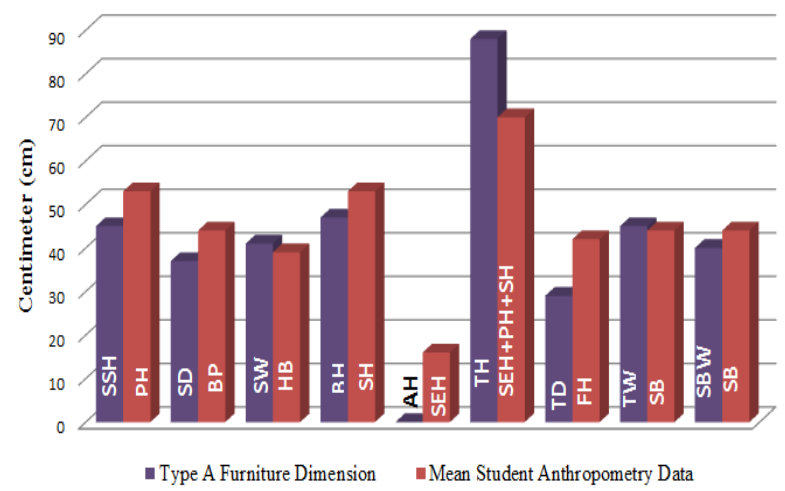

Fig. 3: Comparison of Student Mean Anthropometry Data Mean Anthropometry Data with Type A Furniture Dimensions Dimensions

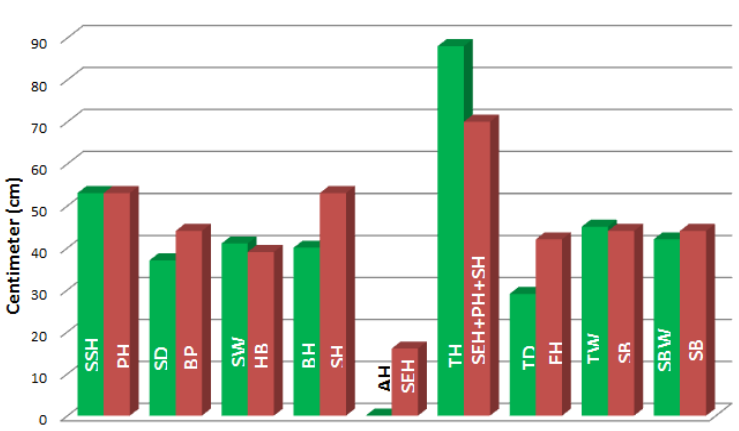

- Type B Furniture Dimension $\quad$ Mean Student Anthropometry Data

Fig. 4: Comparison of Student with Type B Furniture

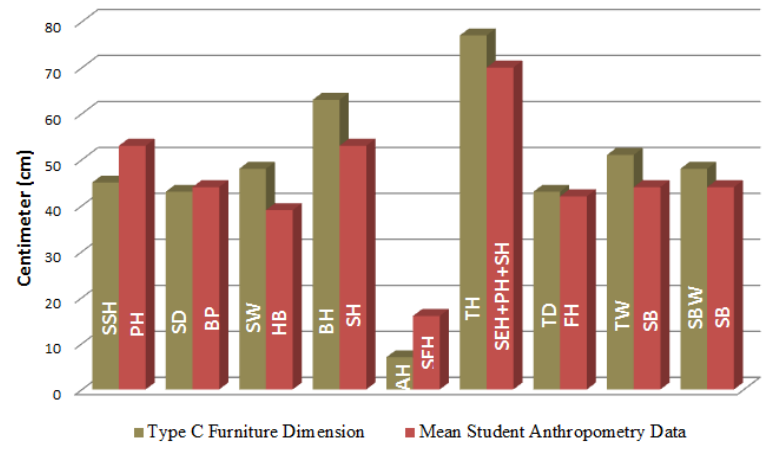

Fig. 5: Comparison of Student Mean Anthropometry Data with Type C Furniture Dimensions

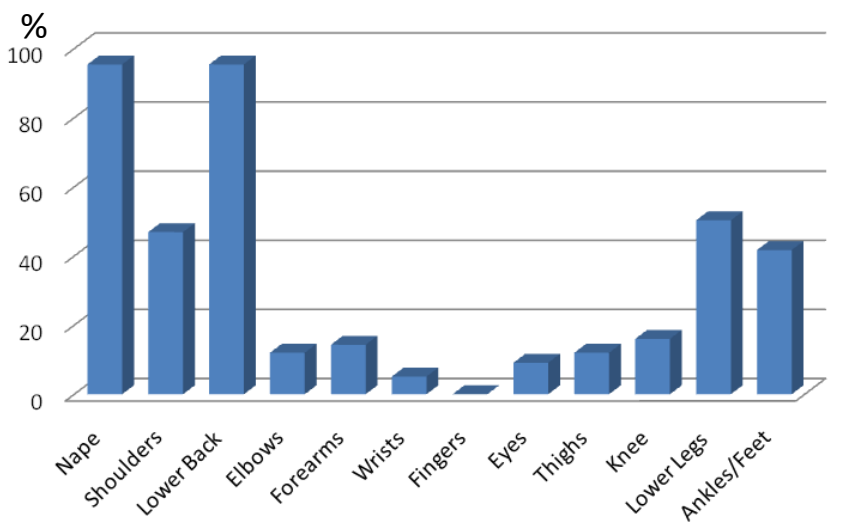

Fig. 6: The Prevalence of MSDs

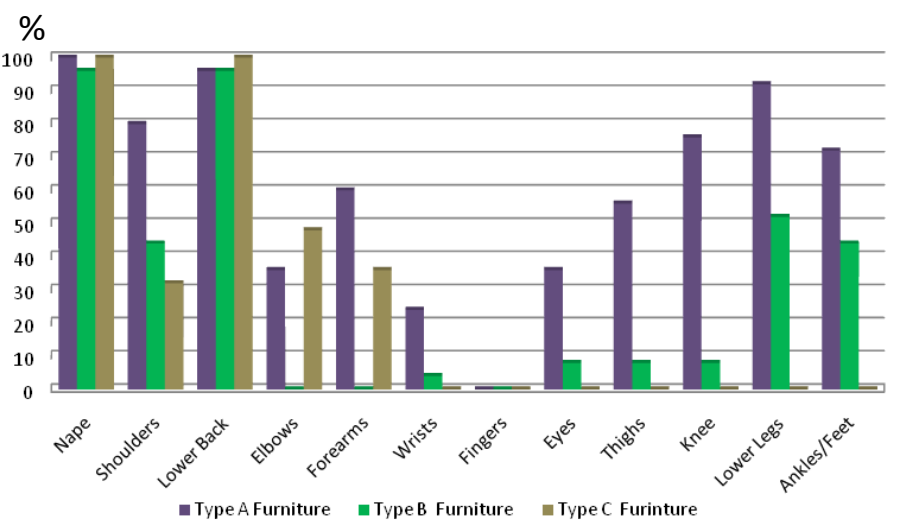

Fig. 7: Prevalence of MSDs Experienced by Students 


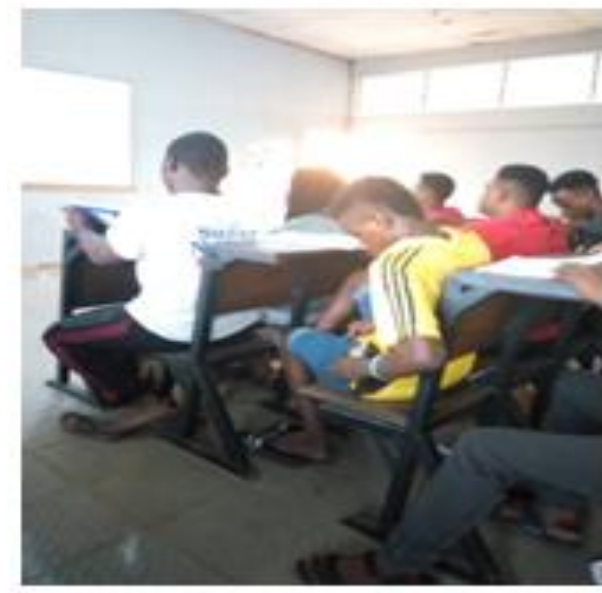

Type A Classroom

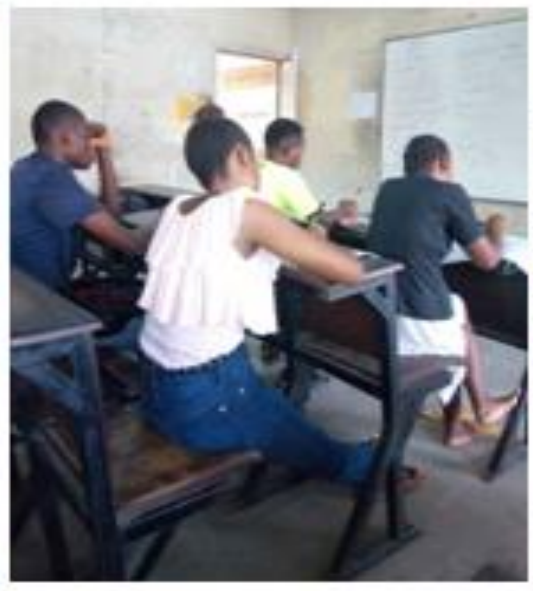

Type B Classroom

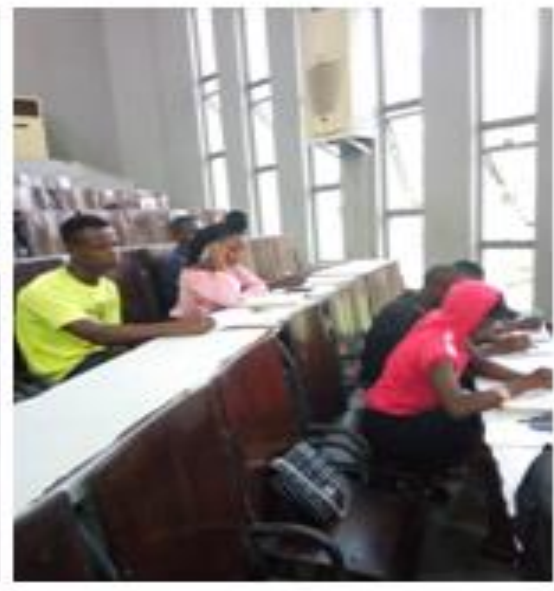

Type C Classroom

Pic. 1

\section{Discussion of Results}

The age of the students was between 17-34 years and the average weight was $60.50 \mathrm{~kg}$. this study revealed that the student had access to three different types of furniture (A, B and C) for use. The ill and improper design of furniture may create many problems for the students such as fatigue, muscular stress, and discomfort/pain in different body parts. The observed students' mean buttock popliteal length $(44 \mathrm{~cm})$ was incompatible with the existing Type A and B furniture $(37 \mathrm{~cm})$ seat depth, but was fairly compatible for Type $\mathrm{C}(43 \mathrm{~cm})$. This Shallow seat depth may cause the user to have the sensation of falling off and result in lack of support of the lower thighs and assume awkward posture. This awkward posture was responsible for the high prevalence of thigh (56\%), knee (76\%), lower legs (92\%) and ankles/feet (72\%) complains from Type A users, because they try to use their legs to support their weight (Fig. 7). However, users of the better suitable type $\mathrm{C}$ chairs reported lower rates of these complaints.

The backrest promotes a straight back while in the sitting posture. It was observed that the students were unable to have a straight back sitting position, as the type $\mathrm{A}$ and $\mathrm{B}$ chairs backrest dimensions where shorter $(47 \mathrm{~cm}$ and $40 \mathrm{~cm})$ respectively, than their mean sitting shoulder height $(53 \mathrm{~cm})$. This resulted in $47 \%$ of the student population experiencing shoulder discomfort (Fig. 6).

The Seat Surface Height of Types A and C $(45 \mathrm{~cm})$ (Table 1), mismatched the mean sitting popliteal height of the students $(53 \mathrm{~cm})$ This indicates that the seats are too low for the students. The students were observed to reach out for use of items on the table making them move their buttocks forward, using the legs to support and assume awkward postures (Pic 1). These students are therefore exposed to the risk of thigh compression/discomforts and restriction in blood circulation, while in class due to awkward positions assumed for hours. This condition therefore explains this study report of the participants complaining of thigh discomfort (Fig. 6). However, the classroom furniture seat width were comfortable, for the student's mean hip breadth (Table 1).

There were no arm rest for Types A and B furniture, which was present for Type C; though was a mismatch for the student sitting elbow height (Pic 1). Also, there were poor spacing between the seats, which may be responsible for the complaints of forearms, elbow and shoulder pains (Fig. 6).

The seat backrest width should be able to fully accommodate the upper part of the body and allow for convenient use of the backrest. This study discovered that the seat backrest width for Type A and B were $40 \mathrm{~cm}$ and $42 \mathrm{~cm}$ respectively, which are less than the students' mean shoulder breadth of $44 \mathrm{~cm}$ (Fig. 3 and 4). This study shows that users of type A furniture had the highest rate of shoulder pains because they had the narrowest and uncomfortable seat backrest(Fig. 7).

The table height (ranged from 77 to $88 \mathrm{~cm}$ ) was higher than the sum of Mean Sitting Elbow Height, Mean Popliteal Height and shoe heel allowance $(70 \mathrm{~cm})$ (Table 1). This mismatch made the students to bend forward and unable to make use of the backrest (Pic 1). This awkward posture, forced them to raise shoulders, resulting in muscle strain on the back and shoulders and discomforts of their shoulders, lower back, forearms and elbow. Also, the students had a mean forearm hand 
length $(42 \mathrm{~cm})$ that were longer than the table depth for Type A and B $(29 \mathrm{~cm})$ (Table 1$)$, thus having reduced work space available for use. This situation can make them place some of their loads or items on their thigh, hence mounting more pressure and pain on the thigh and lower legs (Samira et al., 2013). This finding therefore, justifies their complaints of thigh and lower legs pains. However, students using Type $\mathrm{C}$ furniture with closer table depth dimension $(43 \mathrm{~cm})$ (Table 1$)$ did not complain of pains in the thigh and lower legs (Fig. 7). Also, the mean hip breadth of the student anthropometric data matched the table width, thus accommodating the user's activity (reading and writing) and allows the use of the arms comfortably.

Mandal, (1981) proposed that tables should be at an angle of $15^{\circ}$ towards the user so that the visual angle may be reduced and allow the user to have an upright posture of the trunk, while Chaffin et al., (2006) suggested that the table should have an angle of inclination between $15^{\circ}$ and $20^{\circ}$. However, this study records shows a $1-5^{\circ}$ table slope which will affect their trunk posture. The student population experienced discomforts in their back of neck, shoulders, elbows, forearms, lower back and lower legs (Fig. 6), which may be linked to the poor table slopping.

\section{Conclusion}

Chances of mismatch between the student's anthropometric data and available furniture dimensions thus exist in Nigeria academic Institutions. The ill and improper design of desks have created many ergonomic problems for the students, such as discomfort/pain in different body parts, fatigue, and muscular stress. The most visible risk factors of MSDs are poorly designed furniture, assumed awkward posture on a regular basis, while sitting in the same position for continuous long hours.

\section{References}

1. Aleksandar Z., Goran P., Bozica B., Lidija M., Goran S., Peter L., (2013). The Role of Ergonomics in the Improvement of Quality Education. Faculty of Mechanical Engineering, Belgrade, Serbia. FME Transactions Vol. 43, No 1, 2015, pp. 82. Doi 103.289505

2. Alnaser M., Wughalter E., (2009). Effect of chair design on ratings of discomfort. Work 34:223-234. Doi 23.93703

3. Baharampour S., Nazari J., Dianat I., Asgharijafarabadi M., (2013). Student's body dimensions in relation to classroom furniture. Health Promotion Perspective, 3 (2), pp. 165-174. Doi 37.78769

4. Biswas B., Zahid F., Ara R., Parvez M., Hoque M., (2014). Mismatch between classroom furniture and anthropometric measurements of Bangladeshi primary school students. International Conference on Mechanical, Industrial and Energy Engineering, Khulna, Bangladesh. Doi 50.355766

5. Chaffin D. B., Andersson G. B., and Martin B., (2006). Occupational Biomechanics. New York: Wiley Printing Press INC. 2007 Edition, 14-22. Doi 44.975155

6. Chubineh K., Papageorgiou A., and Jones T.J, (2012). Low back pain in schoolchildren: occurrence and characteristics. Pain 97: 87-92. Doi 76.04754
7. Chung J., Wong T., (2007). Anthropometric evaluation for primary school furniture design. Ergonomics 50 (3), pp. 323334. Doi 78.02561

8. Close S., Bendak K., Al-saleh, Al-khalidi A., (2013). Ergonomic assessment of primary school furniture in United Arab Emirates. Occupational Ergonomics, 11, p. 85-95. Doi 53.510323

9. Corlett E., (2009). Ergonomics and sitting at work. Work, (34), pp. 235-238. Doi 43.370743

10. Dawal M., Ismail Z., Yusuf K., Abdul-Rashid H., Md Shalahim S., Abdullah N., Mohd Kamil N., (2015). Determination of the significant anthropometry dimensions for user-friendly designs of domestic furniture and appliances - experience from a study in Malaysia. Measurement, 59, pp. 205-215). Doi 166.2994

11. Dianat I., Ali K., Asl-Hashemic A., and Bahrampour S., (2013). "Classroom Furniture and Anthropometric Characteristics of Iranian High School Students: Proposed Dimensions Based on Anthropometric Data." Applied Ergonomics 44 (1): 101-108. Doi 158.99379

12. Hafezi R., Mirmohammadi J., Mehrparvar A., Akbari H., Akbari H., (2010). An analysis of anthropometric data on Iranian primary school children. Iranian Journal of Public Health, 39 (4), pp. 78-86. Doi 55.215282

13. John K., Adeyemi J., (2015). Anthropometric data for Tanzania's primary school furniture design. ARPN Journal of Engineering Applied Science, 10 (2), pp. 890-895. Doi 35.55532

14. Johnson O., Onigbinde A., Onasanya S., Emechete A., Gbela T., (2008). An Assessment of Ergonomic Workstations and Pain among Computer Users in Nigerian University Community. Niger Journal of Medical Rehab 13: 7-10. Doi 49.547325

15. Khalid S., Mohamed Z., Riyad A., (2013). Ergonomically adjustable school furniture for male students. Academic Journal of Educational Research and Review; 8(13): 943-955. Doi 35.72941

16. Koskelo R., Vuorikari K., Hänninen O., (2007). Sitting and standing postures are corrected by adjustable furniture with lowered muscle tension in high-school students, Ergonomics 50(10):1643-1656. Doi 151.25757

17. Mandal A. C., (1981). The seated man (Homo Sedens): The seated work position, theory and practice,Applied Ergonomics, Volume 12, Issue 1, 19-26. Doi 132.0802

18. Mokdad M., Al-Ansari M., (2009). Anthropometrics for the design of Bahraini school furniture, International Journal of Industrial Ergonomics 39 (5). pp. 728-735. Doi 42.70143

19. Momodu B., Edosomwan J., Edosomwan T.,(2014). Evaluation of ergonomics deficiencies in Nigeria Computer Workstations. Journal of Ergonomics. Available:http://www.omicsgroup.org/journals/evaluation-ofergonomics-deficiences-in-nigeria-computer-workstation-21657556.S4-008.pdf

20. Musa A. I., Ismaila S. O., Adejuyigbe S. B., Akinyemi O. D. and Abolarin M. S., (2013). 'Comparison of biomechanical and anthropometrical data of Nigeria tertiary institution students with some selected countries', Management Science Letters, Volume 2, 1885-1894. Doi 149.44617

21. Musa A., (2011). Anthropometric evaluations and assessment of school furniture design in Nigeria: a case study of secondary schools in rural area of Odeda, Nigeria. International Journal of Industrial Engineering Computer,2(3), pp. 499-508. Doi 112.030914

22. Nwaogazie A., (2016). Examination of Musculoskeletal Discomfort among Staff and Students of the University of Port Harcourt. Journal of Occupational Safety, 238-243. Doi 44.040356

23. Ogedengbe T., (2015). Ergonomic Appraisal of a Nigerian University Library Department of Mechanical Engineering, the Federal University of Technology, Akure, Nigeria. International Journal of Science and Technology Volume 4 No. 2, 68-74. Doi 67.87847

24. Parcells C., Stommel M., and Hubbard R., (1999). Mismatch of classroom furniture and students body dimensions: Empirical 
findings and health implications, Journal of Adolescent Health 24; 265-273. Doi 106.2659

25. Qutubuddin S., Hebbal S., and Kumar S., (2013). Anthropometric Consideration for Designing Students Desks in Engineering Colleges. International Journal of Current Engineering and Technology, ISSN 2277-4106, pp. 274-281. Doi 51.789394

26. Saarni L., Rimpela A., Nummic T., Kaukiainen A., Salminen J., Nygard C., (2009). Do ergonomically designed school workstations decrease musculoskeletal symptoms in children? A 26-month prospective follow-up study. Application Ergonomics 40:491-499. Doi 143.66289

27. Samira B., Jalil N., Iman D., Mohamad A., (2013). Student's Body Dimensions in Relation to Classroom Furniture. Health Promotion Perspectives, 3(2), 165-174. Doi 43.74907

28. Taimela S., Kujala U., Salminen J., Viljanen T., (1997). The prevalence of low back pain among children and adolescents. A nationwide, cohortbased questionnaire survey in Finland. Spine 22:1132-1136. . Doi 138.32173
29. Troussier B, Tesniere C, Fauconnier J, Grison J, Juvin R, Phelip $\mathrm{X}$ (1999). Comparative study of two different kinds of school furniture among children. Ergonomics; 42(3):516-526. Doi 108.63102

30. Vikat A., Rimpelä M., Salminen J., Rimpelä A., Savolainen A., Virtanen S., (2000). Neck or shoulder pain and low back pain in Finnish adolescents. Scand Journal of Public Health 28(3):164173. . Doi 135.15129

31. Wingrat J., Exner C., (2005). The impact of school furniture on fourth grade children's on-task and sitting behavior in the classroom: A pilot study. Work 25:263-272. . Doi 33.614113

32. Yadollah Z., Mahin G., Shahram B., Darioush B., Nejad S. Mahmood L., (2015). The Relationship between Features of Desks and Chairs and Prevalence of Skeletal Disorders in Primary School Students in Abadan, South West of Iran. International Journal of Pediatrics, Mashhand University of Medical Science, 3949-3956. Doi 50.92631 